\title{
sciendo
}

RURAL SUSTAINABILITY RESEARCH 39(334), 2018

ISSN - 2256-0939

(C) Latvia University of Life Sciences and Technologies, all rights reserved

http://www.llu.lv/en/

\section{Welfare Implications of Domestic Land Grabs Among Rural Households in Delta State, Nigeria}

\author{
*Abimbola O. Adepoju, Scholastica Ewolor and Oluwakemi A. Obayelu \\ University of Ibadan, Ibadan, Oyo State, Nigeria
}

\begin{abstract}
Rural households are displaced from their lands without any plan in place to resettle or compensate them, for a promise of improvement in their living standards. This has not only resulted in a decline in the living standard of the rural populace, in terms of loss of land and livelihoods, the poor are also further marginalized and impoverished. This study examines the welfare implication of domestic land grabs among rural households in Delta State, Nigeria, employing primary data obtained from one hundred and seventy-three representative farming households. Descriptive analysis revealed that majority were low-income earners and engaged in farming as their major occupation. Econometric analysis revealed land size, secondary education, community leaders' influence, compensation and the use to which the grabbed land was put into as some of the significant factors influencing domestic land grabs in the study area. Further, the size of land grabbed, no compensation for the use of land and low farm output were found to have negative effects on the welfare of the farmers. Thus, the need to intensify efforts to ensure that the rural populace is not being unreasonably dispossessed of its lands, becomes imperative. The need for commensurate compensation of rural households whose lands were grabbed and periodical checks on community leaders who positively influence domestic land acquisitions arbitrarily also becomes pertinent for improvement in the welfare of the farmers. This is especially so, if these small-scale farmers are to be significant drivers of global food security.
\end{abstract}

Keywords: welfare, land grabs, rural households, delta state, Nigeria.

\section{Introduction}

Globally, agriculture remains an important and vital sector of the Nigeria economy. In spite of being overshadowed by the oil and gas industry, the sector is the largest contributor to the Nigerian economy (GDP), accounting for $35.4 \%$ of the non-oil foreign exchange earnings and employing about $70-75 \%$ of the active labour force of the population. In Nigeria, the key stakeholders in land and agriculture are the smallholder farming households. They constitute about 70 percent of the active labor force and produce more than 60 percent of the food consumed (NBS, 2015a). Thus, their role in achieving a reduction in poverty and food insecurity cannot be ignored. In other words, farmers continually contribute to the sustainability and welfare of the economy and their efforts in land use is vital for achieving sustained increases in yield and productivity. However, these farmers have a low level of welfare and are of least priority in terms of development assistance and investment terms, owing among other factors to a considerable loss of fertile agricultural land over the years to land grabs. In most cases, rural households are displaced from their lands without any plan in place to resettle or compensate them, for a promise of improvement in their living standards through the promotion of agricultural investment, provision of housing and building of industries in their communities. This has not only resulted in a decline in the living standard of the rural populace in terms of loss of land and livelihood, the poor are also further marginalized and impoverished. In many cases these land deals are accompanied by violence and conflict owing mainly to inadequate compensation of the farmers as well as noninvolvement of those displaced, thus compromising the livelihoods and sustenance of future generations (GRAIN, 2015; Ghatak \& Mookherjee, 2014).

Nigeria's Land Use Act of 1978 gave total control over land to the governing bodies. It specified that, the Governor of each State has control and is to

\footnotetext{
* Corresponding Author's email: abimbola.adepoju@yahoo.com
} 
manage all land in urban areas. However, the Local Government shall control and manage all other land within its area of authority. Land management under this act, thus favored potential investors, private individuals and other corporate bodies in acquiring land (LUA, 1978). The property rights system in Nigeria was reorganized from a mixed private property rights system into a collectivist framework, in which citizens are given ordinary rights of occupancy while the land is owned by government. Thus, Government is charged with the sole responsibility of managing concessions to companies for any use of land, be it agricultural, industrial or other uses. However, this act neglected the more important question of how the various uses to which land is to be put into will be beneficial to the people without resulting into the loss of livelihood. Furthermore, the 1999 constitution recognizes the collective use of land by communities but does not make provision for collective land rights owing to the fact that the state has ownership rights on all land (sections 20,44, 297, and 315). Although the third of the Principles of Environmental Justice "mandates the right to ethical, balanced and responsible uses of land and the twelfth Principle, "affirms the need for providing fair access for all to the various available resources" (Borras, Scoones, \& Hughes, 2011), domestic land grabs in the developing world violates both of these principles.

Over the years, as a result of land grabs, farmers have concentrated on the production of export crops, feed-stocks for the production of bio-fuels and siting of industries instead of staple crops for local consumption (Deininger et al., 2011). This threatens the welfare and survival of the people as food insecurity and lack of jobs, displacement, and reduced living standard becomes the order of the day. Yet, in most economies, large-scale land acquisitions by foreigners have been largely focused on, while the more serious 'land grabbing' in rural societies by national and local elites has been ignored. Thus, the potential adverse effects that could arise from increased demand and competition for land, on the land rights and welfare of the rural people is of immense concern (Cotula et al., 2009). Based on the foregoing and the insufficient empirical information on the effect of land grabs on the livelihoods of rural communities in Nigeria, this study examines the welfare implication of domestic land grabs among rural households in Delta State, Nigeria. The objectives are: to examine the perception of rural households about domestic land grabs, examine the factors influencing domestic land grabs and the effect of domestic land grabs on the welfare of rural households in Delta State.

\section{Materials and Methods}

Delta State was purposively selected for this study because of the wide spread incidence of land grabs in the rural areas of the State. The state lies approximately between Longitude $5^{\circ} 00$ and $6^{\circ} .45^{\prime}$ East and Latitude $5^{\circ} 00$ and $6^{\circ} .30^{\prime}$ North. It is bounded by Edo state in the North, by Anambra state in the East, by Bayelsa state in the South-East, and on the Southern flank is the Bight of Benin on the Atlantic Ocean, which covers about 160 kilometers of the state's coastline. Agriculture remains the major economic mainstay of the people in Delta State (www.deltastate.com.ng).

A multistage sampling procedure was employed in selecting respondents. In the first stage, five Local Government Areas (LGAs) out of twenty-five that have reported domestic land acquisitions were purposively selected in Delta state. The second stage involved the random selection of two communities in each Local Government, while in the third stage, 20 households were selected randomly in each community in the Local Government Areas to make up a total of 200 respondents. However, owing to incomplete questionnaire information, only data from 173 respondents were used for analysis in the study. Descriptive statistics, Likert scale, Logit and the Ordinary least square regression models were the analytical tools employed in the study.

The Logit specification provides a model for observing the likelihood of a rural household experiencing domestic land grab. The logistic regression model shows the relationship between a qualitative dependent variable and several independent variables. In this analysis, experience of land grab (Y) is the dependent variable which assumes the value of 1 if household land was grabbed and 0 if otherwise. The cumulative density function of the Logit regression model is specified as:

$\mathrm{P}=\frac{\exp e}{1+\exp e}$

where $\mathrm{P}$ is the proportion of occurrence and stated explicitly as follows:

$Y i=\beta_{0}+\beta_{1} X_{1}+\beta_{2} X_{2}+\beta_{3} X_{3}+\beta_{4} X_{4}+$

$+\beta_{5} X_{5}+\beta_{6} X_{6}-----+\beta_{12} X_{12}+e$

where,

$\mathrm{Y}_{\mathrm{i}}$ - experience of domestic land grab $(\mathrm{D}=1$ if yes, $0=$ otherwise);

$X_{1}$ - age of household head (years);

$\mathrm{X}_{2}$ - gender $(\mathrm{D}=1$ if male, $0=$ otherwise $)$;

$\mathrm{X}_{3}$ - primary education of household head $(\mathrm{D}=1$ if yes, $0=$ otherwise);

$\mathrm{X}_{4}$ - secondary education of household head $(\mathrm{D}=1$ if yes, $0=$ otherwise); 
$\mathrm{X}_{5}$ - tertiary education of household head ( $\mathrm{D}=1$ if yes, $0=$ otherwise);

$\mathrm{X}_{6}$-marital status $(\mathrm{D}=1$ if married, $0=$ otherwise $)$;

$\mathrm{X}_{7}$ - land size (hectares);

$\mathrm{X}_{8}$ - primary occupation $(\mathrm{D}=1$ if farming,

$0=$ otherwise);

$\mathrm{X}_{9}$ - compensation $(\mathrm{D}=1$ if yes, $0=$ otherwise $)$;

$\mathrm{X}_{10}$ - knowledge of land use $(\mathrm{D}=1$ if yes, $0=$ otherwise);

$\mathrm{X}_{11}$ - political influence $(\mathrm{D}=1$ if yes, $0=$ otherwise $)$;

$X_{12}$ - community leaders influence $(D=1$ if yes,

$0=$ otherwise);

$b_{i}$ - unknown parameters to be estimated;

e - error term.

The Ordinary Least Squares regression model was used to examine the effects of domestic land grabs on rural household welfare. The Ordinary Least Squares (OLS) or linear least squares is a method for estimating the unknown parameters in a linear regression model. Per-capita monthly household expenditure on food and non-food was used to proxy rural household welfare. Based on economic, econometric and statistical criteria, the semi-log functional form was best suited for the analysis after several functional forms were tested. The OLS model is specified as

$Y=X \beta+e$

where $\mathrm{Y}$ is the response variable and $\mathrm{X}$ 's are predictor variables, $\beta$ is the vector of unknown parameters and $\varepsilon$ are unobserved scalar random variables (errors).

The model is stated explicitly as follows:

Ln Yi $=\beta_{0}+\beta_{1} X_{1}+\beta_{2} X_{2}+\beta_{3} X_{3}+\beta_{4} X_{4}+$

$+\beta_{5} X_{5}+\beta_{6} X_{6}--+\beta_{11} X_{11}+e$

where;

$=\log$ of per capita monthly household expenditure on food and non-food;

$X_{1}$ - age of household head (years);

$X_{2}$ - gender of household head $(D=1$ if male, $0=$ otherwise);

$\mathrm{X}_{3}$ - primary education of household head $(\mathrm{D}=1$ if yes, $0=$ otherwise);

$\mathrm{X}_{4}$ - secondary education of household head $(\mathrm{D}=1$ if yes, $0=$ otherwise);

$\mathrm{X}_{5}$ - tertiary education of household head ( $\mathrm{D}=1$ if yes, $0=$ otherwise);

$\mathrm{X}_{6}$ - marital status ( $\mathrm{D}=1$ if married, $0=$ otherwise);

$\mathrm{X}_{7}$ - size of land grabbed (hectares);

$\mathrm{X}_{8}$ - primary occupation $(\mathrm{D}=1$ if farming,

$0=$ otherwise);
$\mathrm{X}_{9}$ - farm output ( $\mathrm{D}=1$ if low, $0=$ otherwise);

$\mathrm{X}_{10}$ - compensation $(\mathrm{D}=1$ if no, $0=$ otherwise);

$=$ unknown parameters to be estimated;

$\mathrm{e}=$ error term.

\section{Results and Discussion}

Table 1 revealed that a larger proportion of the respondents were male with almost four-fifths aged between 46 and 65 years. This implies that most of the respondents were still in their active and productive years. The mean age of the respondents was 577.4 years. Respondents that were married also accounted for more than three-fifths while majority had household sizes comprising of between 6 and 10 persons. About $45.1 \%$ of the respondents had at least primary education with more than half engaged primarily in farming. The mean years of farming were 309.2 years. Further, almost half of the respondents earned income of between NGN 30,000.00 and NGN $60,000.00$. This implies that most of the respondents were low income earners and most likely cultivated their land for food. Mean size of land acquired was 2.61.9 ha, as more than four-fifths of the respondents reported that their land had been grabbed.

\section{Household Perception of Domestic Land Grabs}

A 5-point Likert scale was used in analyzing rural households' perception of land grabs. From the results, most of the respondents perceived domestic land grabs as an occurrence that has negative effects on their welfare and that of their households. This is clearly seen in the perception index generated from the mean of the sum of each statement score which stood at 29.3 . Thus, about $46.2 \%$ of the respondents with indices below the benchmark were favorably disposed to domestic land grabs while more than half of the respondents with indices above the benchmark were unfavorably disposed to domestic land grabs. This result, as presented in Table 2, clearly shows that land grabs is perceived as a major threat to rural households' livelihood, owing mainly to its welfare reducing effects. This result corroborates the findings of Friis and Reenberg (2010) and Dominguez (2010).

\section{Factors Influencing Domestic Land Grabs}

Table 3 presents the results of the Logit regression analysis on the factors influencing domestic land grabs. The Log likelihood ratio of 119.27 and Chisquare value of 114.63 which was significant at $(\mathrm{p}<0.01)$ indicates the overall significance and goodness of fit of the model. Out of the twelve explanatory variables included in the model, six were significant in explaining the likelihood of occurrence of domestic land grabs in the study area. These six variables include: Land size, secondary education, 
Socio-economic Characteristics of the Respondents

Table 1

\begin{tabular}{|c|c|c|}
\hline Variable & Frequency & $\%$ \\
\hline \multicolumn{3}{|l|}{ Gender } \\
\hline Female & 65 & 37.6 \\
\hline Male & 108 & 62.4 \\
\hline \multicolumn{3}{|l|}{ Age } \\
\hline $36-45$ & 3 & 1.7 \\
\hline $46-55$ & 59 & 34.1 \\
\hline $56-65$ & 86 & 42.7 \\
\hline$>65$ & 25 & 21.5 \\
\hline \multicolumn{3}{|l|}{ Marital status } \\
\hline Married & 121 & 69.9 \\
\hline Divorced & 40 & 23.1 \\
\hline Widowed & 12 & 7.0 \\
\hline \multicolumn{3}{|l|}{ Household size } \\
\hline $1-5$ & 36 & 13.9 \\
\hline $6-10$ & 108 & 62.4 \\
\hline $11-15$ & 23 & 9.8 \\
\hline$>16$ & 6 & 1.2 \\
\hline \multicolumn{3}{|l|}{ Educational status } \\
\hline No formal education & 34 & 19.7 \\
\hline Primary education & 78 & 45.1 \\
\hline Secondary education & 39 & 22.5 \\
\hline Tertiary education & 22 & 12.7 \\
\hline \multicolumn{3}{|l|}{ Primary occupation } \\
\hline Farming & 97 & 56.1 \\
\hline Trading & 37 & 21.4 \\
\hline Government job & 39 & 22.5 \\
\hline \multicolumn{3}{|l|}{ Monthly income } \\
\hline$<30000$ & 22 & 13.0 \\
\hline $30000-60000$ & 79 & 47.4 \\
\hline $60001-90000$ & 58 & 34.8 \\
\hline$>90000$ & 14 & 8.4 \\
\hline \multicolumn{3}{|c|}{ Size of Land Acquired (ha) } \\
\hline$<1$ & 4 & 2.8 \\
\hline $1-2$ & 71 & 48.9 \\
\hline$>2$ & 70 & 48.3 \\
\hline Total & 145 & 100 \\
\hline
\end{tabular}

Source: Field survey

primary occupation, community leaders influence, compensation and the knowledge of use to which the acquired land was put into. The result of the marginal effects analysis is discussed in Table 3:
A percentage increase in the size of the land increased its likelihood of being grabbed by $10.4 \%$. This could be attributed to the fact that the bigger the land, the more attractive it is to intending investors

\section{Household Perception Index}

\begin{tabular}{|l|l|l|l|l|}
\hline Perception Indices & Frequency & \% & Mean & SD \\
\cline { 1 - 3 } Low (Favorably disposed) & 80 & 46.2 & 29.30 & 4.44 \\
\cline { 1 - 3 } High (Unfavorably disposed) & 93 & 53.8 & & \\
\hline
\end{tabular}

Source: Field Survey 
Factors Influencing Domestic Land Grabs

Table 3

\begin{tabular}{lllc}
\hline Variables & Coefficients & $\mathbf{Z}$ & Marginal effects \\
\hline Gender of Household Head & 1.317 & 0.89 & 0.104 \\
Age of Household Head & -0.203 & -1.40 & -0.101 \\
Married & -2.475 & -1.50 & -0.205 \\
Land Size & $0.477^{*}$ & 1.91 & 0.401 \\
Primary Education & -2.423 & -1.44 & -0.109 \\
Secondary Education & $-4.975^{* *}$ & -2.10 & -0.411 \\
Tertiary Education & -2.253 & -1.13 & -0.217 \\
Farming & $1.191^{*}$ & 1.76 & 0.303 \\
Political Influence & 0.805 & 0.57 & 0.702 \\
Comm. Leaders Influence & $2.023^{*}$ & 1.76 & 0.107 \\
Compensation & $3.975^{* *}$ & 2.54 & 0.331 \\
Knowledge of Land use & $2.280^{* * *}$ & 2.83 & 0.206 \\
Constant & 6.839 & 0.86 & \\
Prob $>$ chi & 0.0000 & & \\
Log likelihood & -119.27 & & \\
Number of observation & 173 & & \\
LR chi ${ }^{2}(12)$ & 114.63 & & \\
\hline
\end{tabular}

Source: Result of Logistic Regression Analysis

Note: $* * *$ and $* * *$ represent significance level at $10 \%, 5 \%$ and $1 \%$, respectively.

who are not likely to be interested in fragmented land holdings. On the other hand, secondary education of the household head decreased the likelihood of land being grabbed by $41.1 \%$. This could be attributed to the fact that being educated confers on these household heads the ability to at least know their land use rights and thus avoid being unreasonably displaced from their land as well as the ability to bargain effectively with incoming investors. Further, being primarily engaged in farming increased the likelihood of land grabs by $30.3 \%$. This is because farming households as the holders of agricultural land cannot refuse to release their land. In other words, as stipulated by law, they do not have ownership rights but only have land use rights since the land belongs to the state (Nguyen, Phillipe \& Vu, 2010). In addition, households in which influence of community leaders is high, where there is adequate compensation and where there is sufficient knowledge of the use to which the land is to be put into have increased likelihood of about $10.7 \%, 33.1 \%$ and $20.6 \%$ of their land being grabbed respectively. This is because the success of the land grab process rests on the satisfaction and dissatisfaction of these rural households which are greatly influenced by these factors.

Results of the Ordinary Least Squares Regression Analysis

The Ordinary Least Square Regression analysis of per capita total monthly household expenditure (welfare proxy) on predictor variables using the semi-log functional form gave a computed $F$ value of 11.88 which was statistically significant at $1 \%$, indicating that the model has a good fit. The result is as presented in Table 4.

The coefficient of the size of land grabbed was negative and significant implying that the larger the size of the land grabbed, the lower the welfare of the households. This could be as a result of inadequate compensation by the investors or government, coupled with increased living costs as well as the fact that the farmers cultivating these lands lose their livelihoods and are not able to get employment elsewhere. Tertiary education had a positive and significant effect on household welfare, indicating that household heads with a higher level of educational attainment have a higher level of welfare when compared with households with no formal education.

This conforms with apriori expectations as education is expected to confer on a person the ability or allows for the opportunity to diversify livelihood choices which ultimately leads to the improved welfare of the household as a whole. In addition, the coefficient of farm output was negative, indicating that a low level of output decreased the welfare of the households, since low output from farms implies less income for the farm family. Also, as expected, households which had not received any compensation for the use of their land had a lower level of welfare when compared with those that had received compensation. 
Effects of Domestic Land Grab on Household Welfare

Table 4

\begin{tabular}{llll}
\hline Variables & Coefficient & Statistics & P-value (sig) \\
\hline Gender & -0.077 & -1.64 & 0.103 \\
Age & 0.039 & 1.01 & 0.315 \\
Marital status & 0.042 & 0.95 & 0.346 \\
Size of Land grabbed & $-0.070^{* * *}$ & -8.24 & 0.000 \\
Primary education & 0.040 & 0.88 & 0.382 \\
& & & \\
Secondary education & 0.089 & 1.33 & 0.186 \\
Tertiary education & $0.112^{* *}$ & 1.99 & 0.048 \\
Primary occupation & -0.037 & -1.45 & 0.149 \\
Farm output & $-0.075^{*}$ & -1.90 & 0.059 \\
Compensation & $-0.011^{* * *}$ & -2.67 & 0.008 \\
Constant & 8.823 & 11.51 & \\
$\mathrm{R}^{2}$ & 0.423 & & \\
Adjusted R & 0.388 & & \\
F-calculated & 11.880 & & \\
Prob $>$ F & 0.000 & & \\
\hline
\end{tabular}

Source: Result of the Ordinary Least Square Regression Analysis

Note: $* * *$ and $* * *$ represent significance level at $10 \%, 5 \%$ and $1 \%$, respectively

\section{Conclusion}

Various attempts to push farmers off their land have become a global phenomenon in most rural areas of the developing world, where agriculture is the mainstay of the populace and where most of the poor reside. In Nigeria, over recent years, there has been a focus on attracting foreign investment in agriculture. This strategy is in the bid to increase national food production and by extension improve the food security situation in the country. This process involves the identification and acquisition of tracks of agricultural lands for large scale projects by the government and investors. However, in most cases, local farmers are not consulted about the deals and are not aware of any compensation or resettlement plan. Domestic land grabs which are expected to contribute positively to the growth and development of rural communities are thus perceived among rural households' as a negative phenomenon which adversely affects their welfare. Based on the foregoing, the need to step up efforts to ensure that rural households have secure land rights and are not being unreasonably dispossessed of their land becomes imperative. Also, there is the need for commensurate compensation of rural households whose lands were grabbed and periodical checks on community leaders who positively influence domestic land acquisitions arbitrarily. This is pertinent for improvement in the welfare of the farmers especially if these small-scale farmers are to be significant drivers of global food security.

\section{References}

1. Borras, J., Scoones, I. \& Hughes, D. (2011). Small-scale farmers increasingly at risk from global land grabbing. The Guardian.co.uk: Poverty Matters Blog. Retrieved March 22, 2015 from https://www.theguardian.com/ global-development/poverty-matters/2011/ apr/15/risks-over-increasing-global-land deals?INTCMP=ILCNETTXT3788.

2. Cotula, L., Vermeulen, S., Leonard, R., \& Keeley, J. (2009). Land Grab or Development Opportunity? Agricultural Investment and International Land Deals in Africa, IIED/FAO/ IFAD, London/Rome. ISBN: 978-1-84369-7411. Retrieved August 11, 2016 from http://www. fao.org/tempref/docrep/fao/011/ak241e/ak241e. pdf.

3. Deininger, K., Byerlee, D., Lindsay, J., Norton, A., Selod, H., \& Stickler, M. (2011). Rising Global Interest in Farmland: Can it Yield Sustainable and Equitable Benefits? Agriculture and Rural Development. Washington DC, USA: The World Bank.

4. Dominguez, A. (2010). "Why was there still malnutrition in Ethiopia in 2008? Causes and Humanitarian Accountability," Retrieved May 21, 2017, from http://sites.tufts.edu/jha/ archives/640.

5. Friis, C., Reenberg, A. (2010). Land grab in Africa: Emerging land system drivers in a tele-connected world. GLP Report No. 1. 
Copenhagen: GLP-IPO. Retrieved September 14, 2016, from http:// www.ihdp.unu.edu/docs/ Publications/GLP/GLP_report_01.

6. Ghatak, M., Mookherjee, D. (2014). Land acquisition for industrialization and compensation of displaced farmers, J. Dev. Eco. 110: 303-312. DOI:org/10.1016/j.jdeveco.2013.01.001.

7. GRAIN (2015). Dominion Farm's land grab in Nigeria. Retrieved June 18, 2017, from https:// www.grain.org/article/entries/5126-dominionfarm-s-land-grab-in-nigeria.

8. LUA (1978). Nigeria Land Use Act. Retrieved January, 2016, from www.nigeria-law.org/ Land\%20Use\%20Act.htm.
9. NBS (National Bureau of Statistics) (2015a). Nigerian Gross Domestic Product Report, Quarter 4, 2015. Retrieved May, 2017, from https://www.nigerianstat.gov.ng/pdfuploads/ GDP\%20Q4\%202015\%20final.pdf.

10. Nguyen, T. D., Phillipe, L. \& Vu, D. T. (2010). Land conversion to industrialization and its impacts on household food security in Red River Delta, Vietnam. Retrieved October 7, 2016, from http://www.gembloux.ulg.ac.be/ eg/publicationsconsommationalimentaire/ doc_download/155-land-conversion-toindustrialization-and-its-impacts-on-householdfood-security-in-red-river-delta-vietnam. 